\title{
Perancangan Sistem Pakar Diagnosis Penyakit Diabetes Berbasis Web Menggunakan Algoritma Naive Bayes
}

\author{
Yohanes Bowo Widodo ${ }^{1 * *}$, Silvia Ayu Anggraeini ${ }^{2)}$, Tata Sutabri ${ }^{3)}$ \\ 1)2)Program Studi Teknik Informatika, Universitas Mohammad Husni Thamrin \\ ${ }^{3)}$ Program Studi Sistem Informasi, Universitas Respati Indonesia \\ ${ }^{*}$ Correspondence Author: ybowowidodo@gmail.com, Jakarta, Indonesia \\ DOI: https://doi.org/10.37012/jtik.v7i1.507
}

\begin{abstract}
Abstrak
Diabetes merupakan penyakit menahun yang akan diderita seumur hidup oleh penderitanya. Diabetes dapat memicu berbagai komplikasi penyakit berbahaya lainnya, jika terlambat ditangani. Banyak masyarakat yang awalnya tidak tahu bahwa mereka menderita penyakit diabetes karena tidak mempunyai pengetahuan dasar mengenai penyakit diabetes serta mengalami keterbatasan waktu untuk melakukan konsultasi kepada dokter. Tujuan dari penelitian ini adalah merancang dan membangun sebuah sistem pakar yang dapat mendeteksi kemungkinan menderita penyakit diabetes berdasarkan gejala-gejala yang telah dimasukkan. Sistem ini juga memberikan rekomendasi berupa informasi dan solusi terhadap penyakit tersebut. Sistem pakar yang dirancang menerapkan perhitungan algoritma naive bayes. Algoritma Naive bayes merupakan pengklasifikasian dengan nilai probabilitas dan statistik yang memprediksi peluang di masa depan berdasarkan pengalaman di masa sebelumnya. Berdasarkan hasil analisa, sistem ini dapat menangani proses konsultasi pengguna dengan tingkat akurasi yang cukup tinggi. Hasil pengujian sistem pakar diagnosis penyakit diabetes dengan menguji rule diagnosis menggunakan algoritma naive bayes yang dilakukan melalui dataset uji sebanyak 30 kali, maka hasilnya sudah sesuai dengan kepakaran yang didapat melalui data hasil pengujian sistem whitebox dan blackbox testing.
\end{abstract}

Kata kunci: Sistem Pakar, Naive Bayes, Diagnosis penyakit diabetes

\begin{abstract}
Diabetes is a chronic disease that the sufferer will suffer for life. Diabetes can lead to various complications of other dangerous diseases, if handled too late. Many people initially do not know that they have diabetes because they do not have basic knowledge about diabetes and experience limited time to consult a doctor. The purpose of this research is to design and build an expert system that can detect the possibility of suffering from diabetes based on the symptoms that have been entered. This system also provides recommendations in the form of information and solutions to the disease. Expert system designed to apply the calculation of the Naive Bayes algorithm. The Naive Bayes algorithm is a classification with probability values and statistics that predict future opportunities based on previous experience. Based on the analysis results, this system can handle the user consultation process with a fairly high level of accuracy. The results of testing the diabetes diagnosis expert system by testing the rule diagnosis using the Naive Bayes algorithm which is carried out through the test dataset as much as 30 times, then the results are in accordance with the expertise obtained through the data from the whitebox system test results and blackbox testing.
\end{abstract}

Keywords: Expert System, Naive Bayes, Diagnosis of diabetes

\section{PENDAHULUAN}

Diabetes adalah penyakit kronis yang ditimbulkan karena kekurangan produksi insulin (hormon yang diproduksi oleh pankreas untuk mengatur tingkat glukosa) dalam tubuh manusia. Glukosa merupakan sumber energi utama bagi sel tubuh. Kurangnya sekresi insulin menyebabkan kadar glukosa darah meningkat dan melebihi batas normal yang seharusnya 
ada dalam darah, sehingga terjadi penumpukan glukosa. Glukosa yang menumpuk di dalam darah karena tidak diserap sel tubuh dengan baik dapat menimbulkan berbagai gangguan organ tubuh. Penyakit diabetes merupakan penyakit yang tidak bisa dianggap remeh dan perlu ditangani dengan cepat. Jika penyakit diabetes tidak dikontrol dengan baik, maka dapat menimbulkan berbagai komplikasi yang membahayakan nyawa penderita.

Sistem pakar (Expert System) merupakan salah satu cabang Artificial Intelligence (AI), dimana suatu program komputer yang mengandung pengetahuan dari satu atau lebih pakar manusia dalam memecahkan suatu permasalahan secara spesifik. Implementasi sistem pakar ke dalam komputer dapat menghasilkan beberapa manfaat seperti keakurasian, kecepatan, dan dapat di akses kapanpun sehingga dapat meringankan tugas dari para pakar di bidangnya. Salah satu penerapan sistem pakar dalam bidang kesehatan adalah berupa diagnosis penyakit, konsultasi penjagaan kesehatan sampai pemberian solusi dari hasil diagnosa.

Agar mempermudah bidang kedokteran untuk mendiagnosis penyakit sehingga lebih tepat dalam menyelesaikan masalah melalui sistem pakar digunakan algoritma Naive Bayes. Algoritma Naive Bayes merupakan sebuah metoda pengklasifikasian dangan menggunakan metode probabilitas dan statistik. Algoritma Naive Bayes memprediksi peluang di masa depan berdasarkan pengalaman di masa sebelumnya. Ciri utama dari Algoritma Naive Bayes adalah asumsi yang sangat kuat (naif) akan independensi dari masing-masing kondisi / kejadian. Berdasarkan latar belakang diatas, dilakukan penelitian tentang system pakar dengan algoritma Naïve Bayes agar dapat memberikan informasi yang tepat kepada masyarakat mengenai penyakit diabetes yang diderita, serta mendapatkan solusi pengobatan dari hasil diagnosa tersebut.

Penggalian informasi melalui jurnal penelitian terdahulu dilakukan untuk mendapatkan gambaran permasalahan yang bisa dijadikan sebagai dasar penulisan latar belakang masalah dengan ringkasan teori-teori yang relevan. Berikut adalah beberapa jurnal penelitian terdahulu yang dijadikan sebagai konsep dasar:

1. Perancangan Sistem Pakar Diagnosa Penyakit Diabetes Melitus Menggunakan Metode Forward Chaining Berbasis Web.

Adjeng Nawang Gumilar (2016:4) menjelaskan bahwa Diabetes Melitus merupakan suatu penyakit menahun yang ditandai dengan kadar glukosa darah (gula darah) melebihi nilai normal. Menurut Badan Kesehatan Dunia (WHO), Indonesia kini menempati urutan ke-4 terbesar di dunia setelah India, China, dan Amerika Serikat 
dalam jumlah penderita diabetes. Banyak orang awalnya tidak tahu bahwa mereka menderita Diabetes Mellitus. Oleh karena itu diperlukan suatu alat atau sistem yang memiliki kemampuan layaknya seorang dokter dalam mendiagnosa penyakit. Sistem tersebut adalah sistem pakar yang berusaha mengadopsi pengetahuan manusia ke dalam komputer agar dapat menyelesaikan masalah seperti yang biasa dilakukan oleh pakar. Penelitian ini bertujuan untuk mengimplementasikan metode Forward Chaining pada sistem diagnosa jenis penyakit Diabetes Mellitus. Metode ini memberikan ruang pada pakar dalam memberikan nilai kepercayaan pada pengetahuan yang diungkapkannya.

2. Rancang Bangun Aplikasi Clinical Pathway Penyakit Kandungan Pada Ibu Hamil Menggunakan Algoritma Naive Bayes

Menurut Ahmad Adi Husada (2016) Clinical Pathway merupakan pedoman kolaboratif untuk merawat pasien yang berfokus pada diagnosis, masalah klinis DNA tahapan pelayanan. Penyakit kandungan merupakan pernyakit yang terdapat pada sistem reproduksi wanita bagi ibu hamil, berbahaya jika tidak segera mendapatkan penanganan lebih lanjut. Pada sistem ini menggunakan perhitungan naive bayes sebagai algoritma pengklasifikasian dari diagnosa. Alogritma naive bayes adalah salah satu algoritma yang kompetitif dalam proses klasifikasi dengan menggunakan asumsi tidak ada kaitan antar atribut (independen). Pada sistem ini, dicoba untuk mengimplementasikan algoritma naive bayes kedalam sebuah sistem berbasis desktop. Sistem klasifikasi ini diawali dengan memasukkan variabel dari data uji kemudian diproses dengan algoritma naive bayes, sehingga mendapatkan hasil diagnosa yang sesuai. Hasil klasifikasi ini berupa diagnosa dengan menyertakan gejala-gejala yang muncul serta saran yang bisa dilakukan. Dari 60 data yang di uji cobakan menggunakan sistem klasifikasi, maka sistem yang dibangun memiliki kinerja yang cukup baik yaitu dengan tingkat akurasi mencapai 83,3\%.

3. Pemodelan Sistem Pakar Untuk Menentukan Penyakit Diabetes Mellitus Menggunakan Metode Naive Bayes Studi Kasus: Puskesmas Poncokusumo Malang. Pada Jurnal Pengembangan Teknologi Informasi dan Ilmu Komputer yang ditulis oleh Irwan Andryanto, Edy Santoso, dan Suprapto (2018) dijelaskan bahwa pencegahan penyakit diabetes mellitus dapat dilakukan jika gejala-gejala penyakit dapat diketahui sejak dini. Pengetahuan akan gejala penyakit diabetes mellitus dapat dilakukan dengan menggunakan sistem pakar. Salah satu metode yang dapat 
digunakan untuk mengetahui gejala penyakit diabetes mellitus adalah metode Naive Bayes. Metode Bayes merupakan pendekatan statistik untuk melakukan inferensi induksi pada persoalan klasifikasi. Metode ini menggunakan probabilitas bersyarat sebagai dasarnya. Hasil pengujian fungsional menghasilkan nilai 100\%. Hal ini menunjukkan bahwa sistem telah berjalan dengan baik dan sesuai dengan daftar kebutuhan yang diharapkan. Semakin banyak data training yang digunakan maka semakin tinggi akurasi sistem. Hasil pengujian akurasi diperoleh nilai akurasi terbaik $100 \%$ dengan jumlah data training sebanyak 140.

\section{METODE}

Algoritma adalah susunan yang logis dan sistematis untuk memecahkan suatu masalah atau untuk mencapai suatu tujuan tertentu. Pada dunia informatika, algoritma berperan penting dalam pengembangan dan pembangunan sebuah software. Naive Bayes merupakan sebuah pengklasifikasian probabilistik sederhana yang menghitung sekumpulan probabilitas dengan menjumlahkan frekuensi dan kombinasi nilai dari dataset yang diberikan. Algoritma mengunakan teorema Bayes dan mengasumsikan semua atribut independen atau tidak saling ketergantungan yang diberikan oleh nilai pada variabel kelas.

Definisi lain mengatakan Naive Bayes merupakan pengklasifikasian dengan metode probabilitas dan statistik yang dikemukan oleh ilmuwan Inggris Thomas Bayes, yaitu memprediksi peluang di masa depan berdasarkan pengalaman di masa sebelumnya. Naive Bayes didasarkan pada asumsi penyederhanaan bahwa nilai atribut secara kondisional saling bebas jika diberikan nilai output. Dengan kata lain, diberikan nilai output, probabilitas mengamati secara bersama adalah produk dari probabilitas individu.

Keuntungan penggunaan Naive Bayes adalah bahwa metode ini hanya membutuhkan jumlah data pelatihan (Training Data) yang kecil untuk menentukan estimasi paremeter yang diperlukan dalam proses pengklasifikasian. Naive Bayes sering bekerja jauh lebih baik dalam kebanyakan situasi dunia nyata yang kompleks dari pada yang diharapkan. (Alfa Shaleh: 2016)

Persamaan dari teorema Bayes adalah :

$$
\boldsymbol{P}(\boldsymbol{H} \mid \boldsymbol{X})=\frac{\mathbf{P}(\mathbf{X} \mid \mathbf{H}) \mathbf{P}(\mathbf{H})}{\boldsymbol{P}(\boldsymbol{X})}
$$

Keterangan : 
$\mathrm{X} \quad$ : Data dengan class yang belum diketahui

H : Hipotesis data merupakan suatu class spesifik

$\mathrm{P}(\mathrm{H} \mid \mathrm{X})$ : Probabilitas hipotesis $\mathrm{H}$ berdasar kondisi $\mathrm{X}$ (posteriori probabilitas)

$\mathrm{P}(\mathrm{H}) \quad$ : Probabilitas hipotesis $\mathrm{H}$ (prior probabilitas)

$\mathrm{P}(\mathrm{X} \mid \mathrm{H})$ : Probabilitas $\mathrm{X}$ berdasarkan kondisi pada hipotesis $\mathrm{H}$

$\mathrm{P}(\mathrm{X}) \quad$ : Probabilitas $\mathrm{X}$

Untuk menjelaskan metode Naive Bayes, perlu diketahui bahwa proses klasifikasi memerlukan sejumlah petunjuk untuk menentukan kelas apa yang cocok bagi sampel yang dianalisis tersebut. Karena itu, metode Naive Bayes di atas disesuaikan sebagai berikut:

$$
P(C \mid F 1 \ldots F n)=\frac{P(C) P(F 1 \ldots F n \mid C)}{P(F 1 \ldots F n)}
$$

Di mana Variabel C merepresentasikan kelas, sementara variabel $\mathrm{F} 1 \quad \ldots \quad$ Fn merepresentasikan karakteristik petunjuk yang dibutuhkan untuk melakukan klasifikasi. Maka rumus tersebut menjelaskan bahwa peluang masuknya sampel karakteristik tertentu dalam kelas C (Posterior) adalah peluang munculnya kelas C (sebelum masuknya sampel tersebut, seringkali disebut prior), dikali dengan peluang kemunculan karakteristikkarakteristik sampel pada kelas C (disebut juga likelihood), dibagi dengan peluang kemunculan karakteristik-karakteristik sampel secara global (disebut juga evidence). Karena itu, rumus di atas dapat pula ditulis secara sederhana sebagai berikut:

$$
\text { Posterior }=\frac{\text { prior } x \text { likelihood }}{\text { evidence }}
$$

Nilai Evidence selalu tetap untuk setiap kelas pada satu sampel. Nilai dari posterior tersebut nantinya akan dibandingkan dengan nilai-nilai posterior kelas lainnya untuk menentukan ke kelas apa suatu sampel akan diklasifikasikan. Penjabaran lebih lanjut rumus Bayes tersebut dilakukan dengan menjabarkan $(C \mid F 1, \ldots, F n)$ menggunakan aturan perkalian sebagai berikut:

$$
\begin{aligned}
& P\left(C \mid F_{1}, \ldots, F_{n}=P(C) P\left(F_{1}, \ldots, F_{n} \mid C\right)\right. \\
& =P(C) P\left(F_{1} \mid C\right) P\left(F_{2}, \ldots, F_{n} \mid C, F_{1}\right)
\end{aligned}
$$




$$
\begin{aligned}
& =P(C) P\left(F_{1} \mid C\right) P\left(F_{2} \mid C, F_{1}\right) P\left(F_{3}, \ldots, F_{n} \mid C, F_{1}, F_{2}\right. \\
& =(C) P\left(F_{1} \mid C\right) P\left(F_{2} \mid C, F_{1}\right) P\left(F_{3} \mid C, F_{1}, F_{2}\right) P\left(F_{4}, \ldots, F_{n} \mid C, F_{1}, F_{2}, F_{3}\right) \\
& =P(C) P\left(F_{1} \mid C\right) P\left(F_{2} \mid C, F_{1}\right) P\left(F_{3} \mid C, F_{1}, F_{2}\right) \ldots P\left(F_{n} \mid C, F_{1}, F_{2}, F_{3}, \ldots, F_{n-1}\right)
\end{aligned}
$$

Dapat dilihat bahwa hasil penjabaran tersebut menyebabkan semakin banyak dan semakin kompleksnya faktor-faktor syarat yang mempengaruhi nilai probabilitas, yang hampir mustahil untuk dianalisa satu persatu. Akibatnya, perhitungan tersebut menjadi sulit untuk dilakukan. Di sinilah digunakan asumsi independensi yang sangat tinggi (naif), bahwa masing-masing petunjuk (F1, F2...Fn) saling bebas (independen) satu sama lain. Dengan asumsi tersebut, maka berlaku suatu kesamaan sebagai berikut:

$$
P\left(F_{i} \mid F_{j}\right)=\frac{P\left(F_{i} \cap F_{j}\right)}{P\left(F_{j}\right)}=\frac{P\left(F_{i}\right) P\left(F_{j}\right)}{P\left(F_{j}\right)}=P\left(F_{i}\right)
$$

Untuk $i \neq j$, sehingga

$$
P\left(F_{i} \mid C, F_{j}\right)=P\left(F_{i} \mid C\right)
$$

Persamaan di atas merupakan model dari teorema Nä̈ve Bayes yang selanjutnya akan digunakan dalam proses klasifikasi. Untuk klasifikasi dengan data kontinyu digunakan rumus Densitas Gauss:

$$
P\left(X_{i}=x_{i} \mid Y=y_{j}\right)=\frac{1}{\sqrt{2 \pi \sigma_{i j}}} e^{-\frac{\left(x_{i}-\mu_{i j}\right)^{2}}{2 \sigma^{2} i j}}
$$

\section{Keterangan :}

$P \quad$ : Peluang

$\boldsymbol{X}_{\boldsymbol{i}} \quad$ : Atribut ke $i$

$\boldsymbol{x}_{\boldsymbol{i}} \quad$ : Nilai atribut ke $i$

$Y \quad$ : Kelas yang di cari

$\boldsymbol{y}_{\boldsymbol{i}} \quad$ : Sub kelas $Y$ yang dicari

$\boldsymbol{\mu}:$ Mean, menyatakan rata-rata dari seluruh atribut

$\boldsymbol{\sigma}$ : Devisi standar, menyatakan varian dari seluruh atribut. 


\section{HASIL DAN PEMBAHASAN}

Dalam pengembangan sistem pakar diagnosis penyakit diabetes, digunakan UML (Unifed Modelling Language) untuk menguraikan langkah-langkah yang akan ditempuh dalam perancangan sistem. Gambar 1 berikut ini adalah use case diagram dari Sistem Pakar.

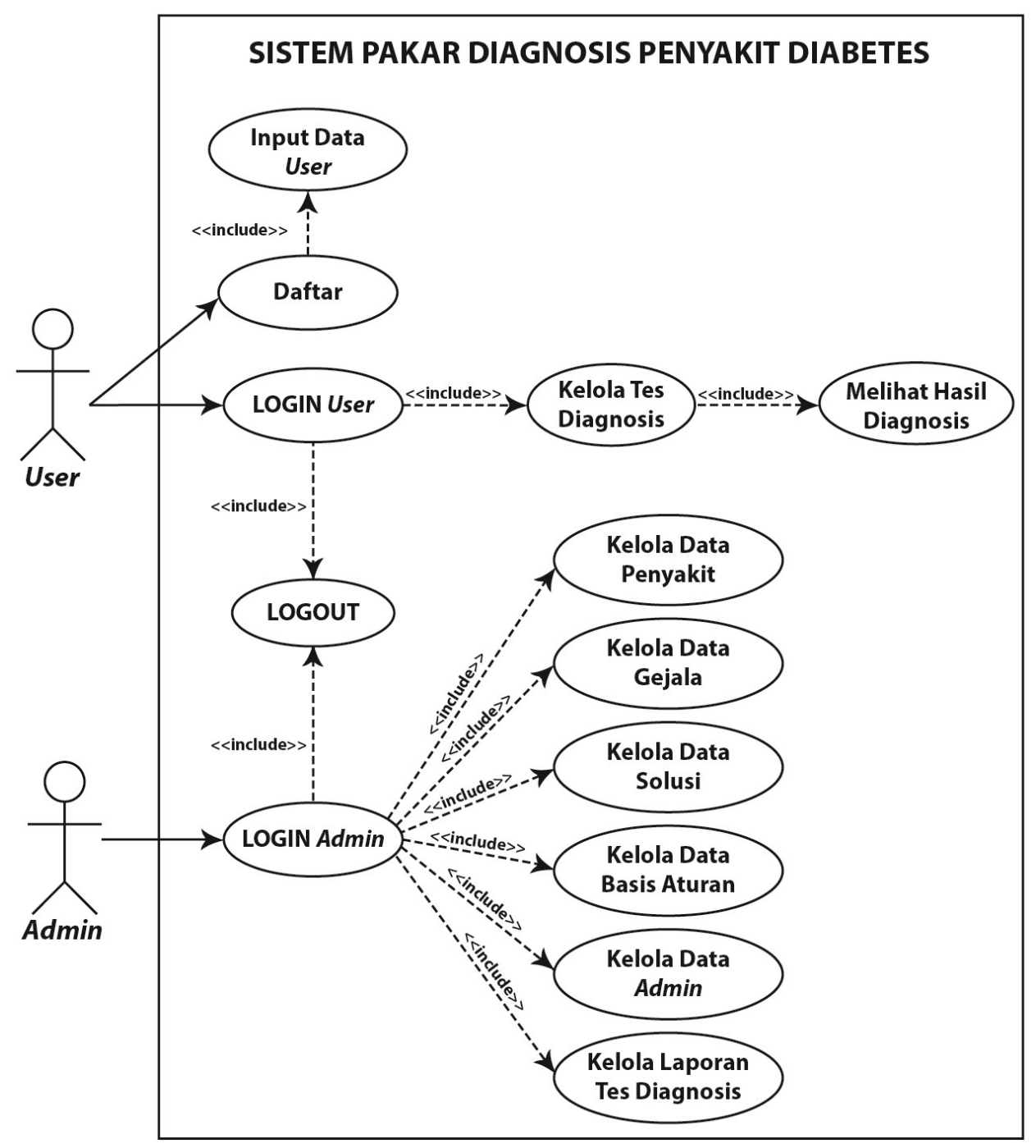

Gambar 1. Use Case Diagram Sistem Pakar

Selanjutnya pada gambar 2 adalah Class Diagram dari Sistem Pakar. 


\begin{tabular}{|c|c|c|}
\hline daftar_penyakit & basis_aturan & daftar_gejala \\
\hline \multirow{2}{*}{$\begin{array}{l}\text { + id_penyakit* : varchar } \\
\text { + nama_penyakit : varchar } \\
\text { + keterangan : varchar } \\
\text { + npenyakit : double }\end{array}$} & \multirow{6}{*}{$\begin{array}{l}\text { + id_gejala** : varchar } \\
\text { + pertanyaan: varchar } \\
\text { + fakta_ya:varchar } \\
\text { + fakta_tidak: varchar } \\
\text { + ngejala_dm1 :double } \\
\text { + ngejala_dm2: double } \\
\text { + ngejala_dm3:double } \\
\text { + ngejala_gestasional : double } \\
\text { + ngejala_lada : double } \\
\text { + ngejala_mody: double } \\
\text { + ngejala_double : double } \\
\text { + ngejala_steroid :double } \\
\text { + ngejala_brittle:double } \\
\text { + ngejala_sekunder:double } \\
\text { + ngejala_insipidus :double } \\
\text { + ngejala_juvenille: double } \\
\text { + rute:varchar } \\
\text { + status: varchar } \\
\text { + id_penyakit** : int }\end{array}$} & $\begin{array}{l}\text { + id_gejala* : varchar } \\
\text { + gejala : varchar }\end{array}$ \\
\hline & & \multirow{2}{*}{$\begin{array}{l}\text { + add() } \\
\text { + update() } \\
\text { + delete() } \\
+ \text { read }()\end{array}$} \\
\hline $\begin{array}{l}+ \text { add() } \\
+ \text { update() } \\
+ \text { delete() } \\
+ \text { read() }\end{array}$ & & \\
\hline daftar_solusi & & admin \\
\hline $\begin{array}{l}\text { + id_solusi* : varchar } \\
\text { + solusi : varchar } \\
\text { + id_penyakit** }{ }^{*} \text { varchar }\end{array}$ & & \multirow{2}{*}{$\begin{array}{l}\text { + admin_id* : int } \\
\text { + firstname : varchar } \\
\text { + lastname: varchar } \\
\text { + username: varchar } \\
\text { + password : varchar } \\
\text { + email : varchar } \\
\text { + adminthumbnails : varchar }\end{array}$} \\
\hline $\begin{array}{l}+ \text { add }() \\
+ \text { update() } \\
+ \text { delete() } \\
+ \text { read() }\end{array}$ & & \\
\hline daftar_user & \multirow{4}{*}{$\begin{array}{l}\text { + add() } \\
\text { + update }() \\
+ \text { delete() } \\
+ \text { read }() \\
\end{array}$} & \multirow{4}{*}{$\begin{array}{l}\text { + add() } \\
\text { + update() } \\
\text { + delete( }) \\
\text { + read() }\end{array}$} \\
\hline $\begin{array}{l}\text { + id_user*: int } \\
\text { + nama:varchar }\end{array}$ & & \\
\hline $\begin{array}{l}\text { + password : varchar } \\
\text { + jenis_kelamin : varchar } \\
\text { + tgl_lahir: date } \\
\text { + tgl_diagnosa : date } \\
\text { + Keterangan : varchar }\end{array}$ & & \\
\hline $\begin{array}{l}\text { + add() } \\
+ \text { update }() \\
+\operatorname{read}()\end{array}$ & & \\
\hline
\end{tabular}

Gambar 2. Class Diagram Sistem Pakar

Entity Relationship Diagram (ERD) adalah model konseptual yang mendeskripsikan hubungan antara penyimpanan data atau file data dari sistem pakar yang akan dibuat. Berikut ini adalah gambaran Entity Relationship Diagram (ERD) sistem usulan yang akan diterapkan pada sistem pakar: 


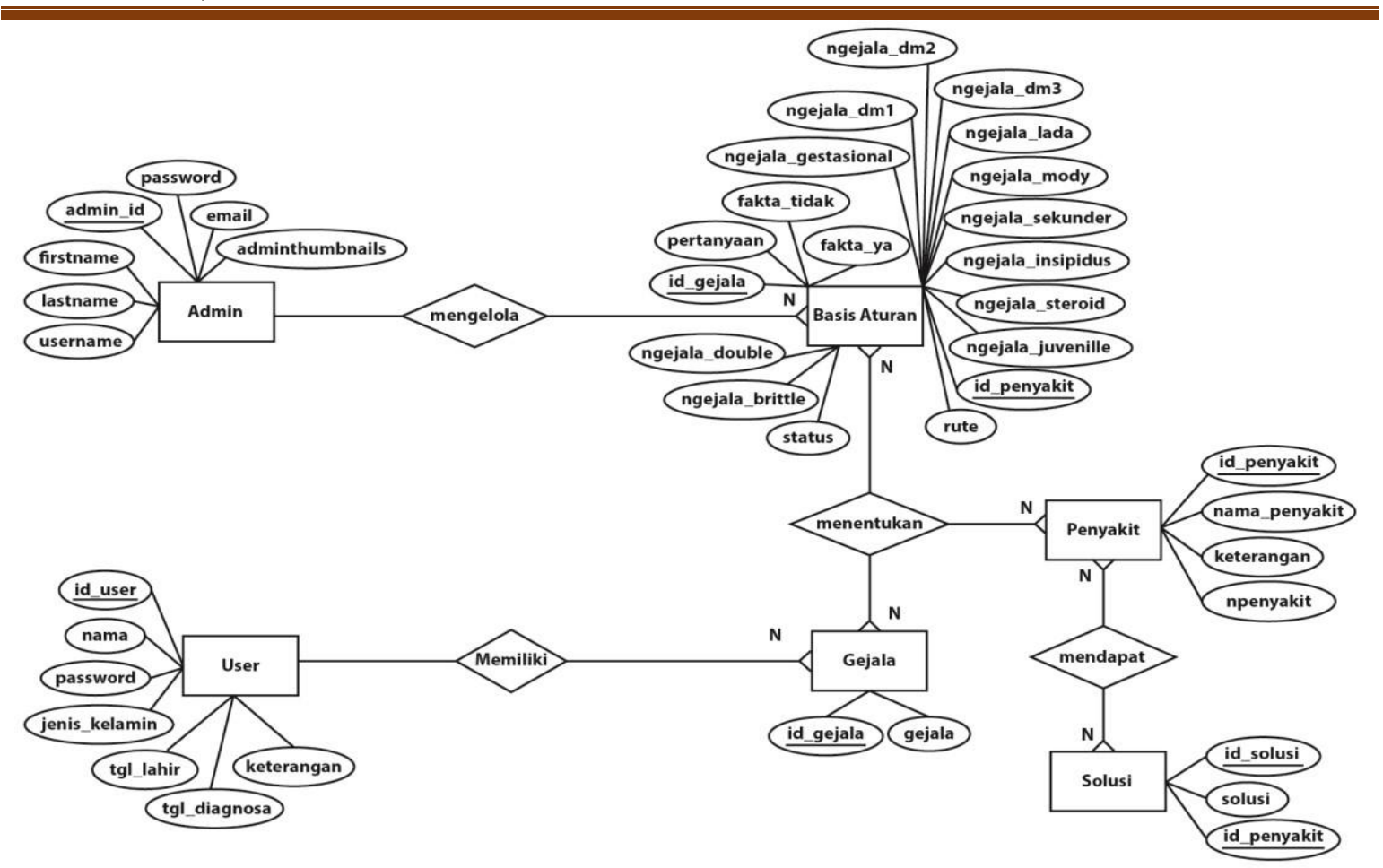

Gambar 3. Entity Relationship Diagram Sistem Usulan

Tampilan halaman utama berfungsi menampilkan menu utama yang terdiri dari home akses menuju login pakar, tentang diabetes, tes diagnosis diabetes, informasi layanan sistem pakar, dan metode yang dapat dilihat oleh user dan admin.

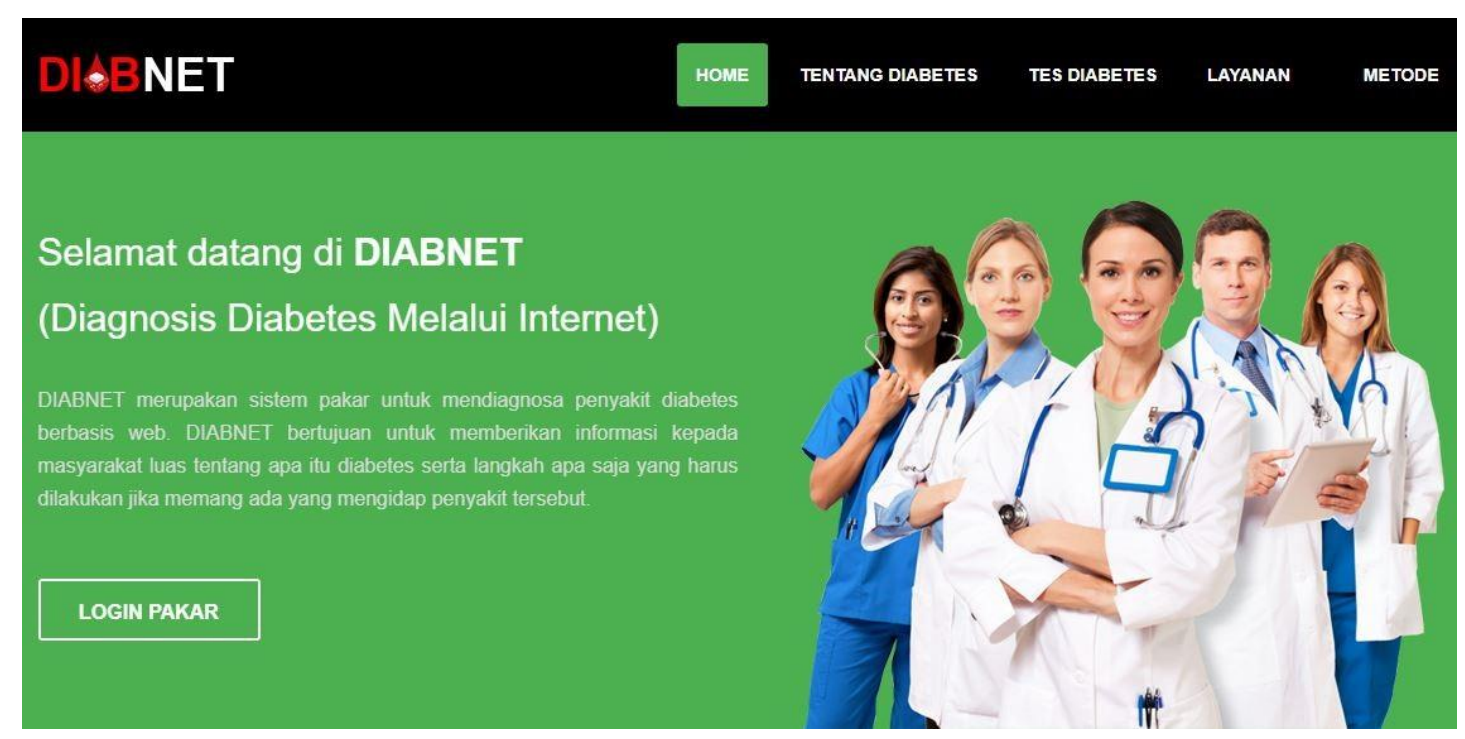

Gambar 4. Tampilan Halaman Utama

Pada halaman tes diagnosis, user harus menjawab berbagai macam pertanyaan seputar kondisi gejala yang dialami dengan memilih tombol benar atau tidak untuk mendapatkan hasil diagnosis. 


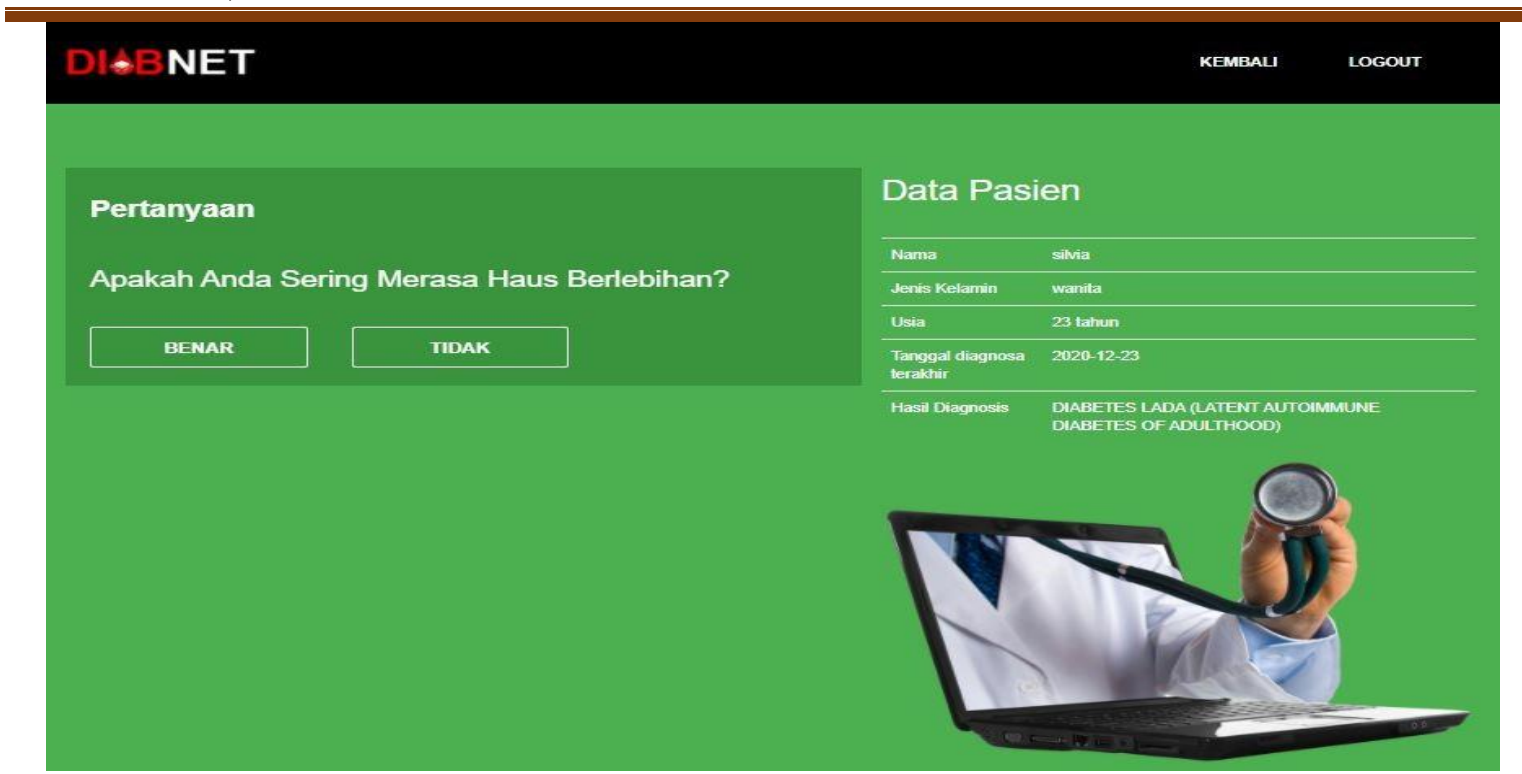

Gambar 5. Tampilan Halaman Tes Diagnosis

Pada gambar 6, valaman ini menampilkan hasil dari diagnosa sistem pakar berupa jenis diabetes yang dialami oleh user, penjelasan singkat mengenai diabetes yang diderita, cara penanganannya serta persentase kemungkinan penyakit berdasarkan pada gejala-gejala yang telah dipilih sebelumnya oleh user.

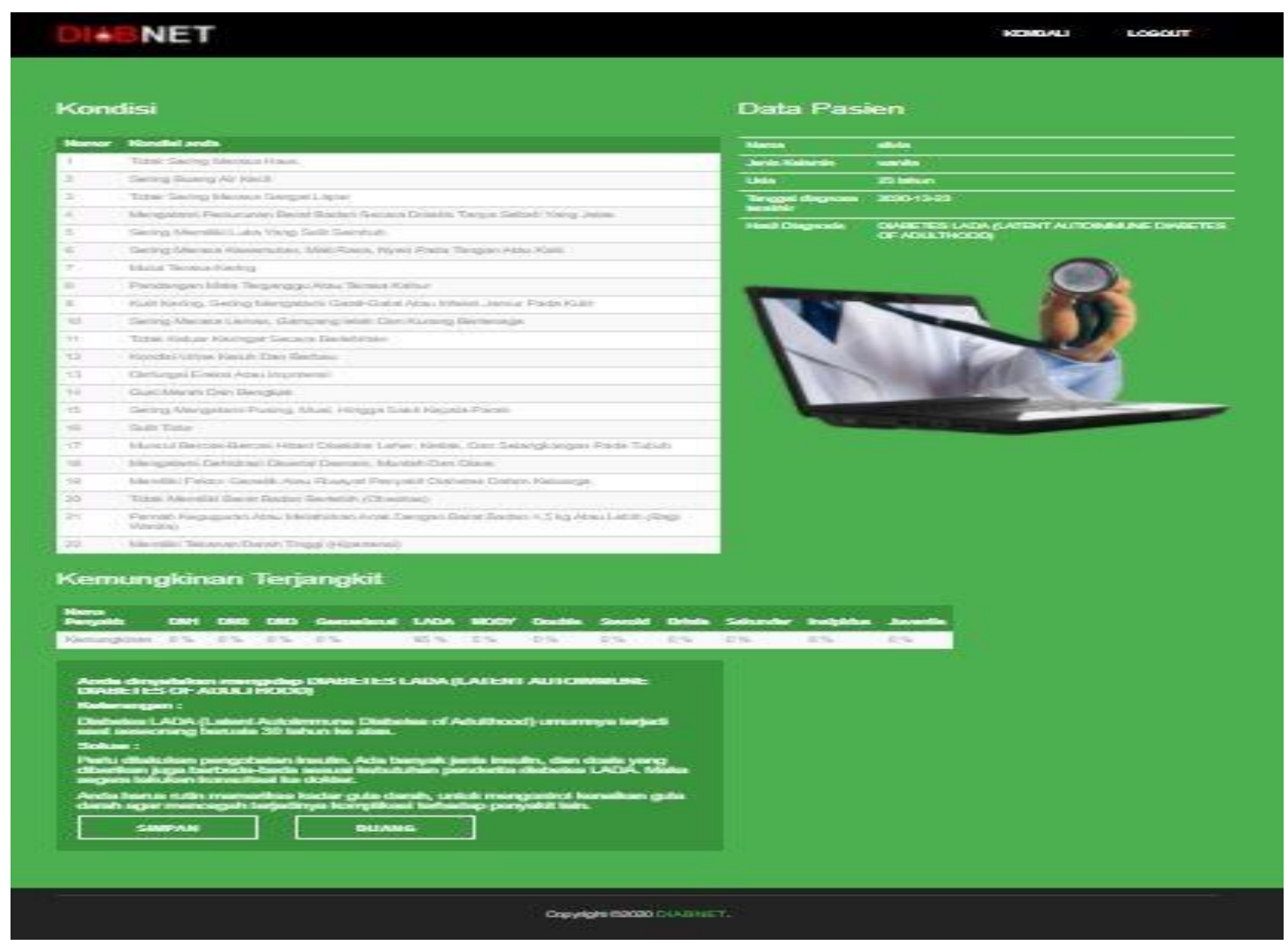

Gambar 6. Tampilan Halaman Hasil Diagnosis 


\section{KESIMPULAN DAN REKOMENDASI}

Berdasarkan hasil pengujian sistem pakar diagnosis penyakit diabetes dengan menggunakan rule algoritma naive bayes yang dilakukan melalui dataset uji pasien sebanyak 30 kali, maka hasilnya sudah sesuai dengan nilai kepakaran yang didapat melalui data hasil pengujian sistem whitebox dan blackbox testing. Pada penelitian ini tentu masih banyak kekurangan yang dapat disempurnakan lagi pada penelitian berikutnya. Agar aplikasi ini dapat menjadi lebih sempurna. Terdapat beberapa saran yang dapat diberikan diantaranya :

1. Dapat membuat rule diagnosa penyakit diabetes menggunakan algoritma yang lebih akurat selain algoritma naive bayes.

2. Menambahkan fitur chat secara langsung dengan dokter ahli penyakit dalam yang menangani diabetes pada sistem sehingga pengguna bisa mendapatkan rekomendasi dari dokter.

\section{REFERENSI}

Andryanto, I., Santoso, E., dan Suprapto. 2018. Pemodelan Sistem Pakar Untuk Menentukan Penyakit Diabetes Mellitus Menggunakan Metode Naive Bayes Studi Kasus : Puskesmas Poncokusumo Malang. Jurnal Pengembangan Teknologi Informasi dan Ilmu Komputer, 2(2): $880-887$.

Dantes, R.G., Setemen, K., Marti, N.W., Arthana, I.K.R., Mahedi, K.S., dan Suputra, P.M. 2019. Pengantar Basis Data. Penerbit: PT. Raja Garafindo Persada. Depok.

Enterprise, Jubilee. 2017. Otodidak MySQL Untuk Pemula. Penerbit: PT. Elex Media Komputindo. Jakarta.

Gumilar, Adjeng Nawang. 2016. Perancangan Sistem Pakar Diagnosa Penyakit Diabetes Melitus Menggunakan Metode Forward Chaining Berbasis Web. Skripsi Program S1 Sistem Informasi Universitas Nusantara PGRI. Surabaya.

Hidayat, W., Wandanaya, A.B. dan Fadriansyah, R., 2016. Perancangan Video Profile Sebagai Media Promosi Dan Informasi Di SMK Avicena Rajeg Tangerang. Jurnal Cerita, 2(1): 56-69.

Husada, Ahmad Adi. 2016. Rancang Bangun Aplikasi Clinical Pathway Penyakit Kandungan Pada Ibu Hamil Menggunakan Algoritma Naive Bayes. http://eprints.umm.ac.id/28092. 25 April 2016 (10:07 WIB).

Kurniawan, Chalid. 2018. Komplikasi Pada Mata Karena Diabetes-Pencegahan dan Penanganan Diabetes Pada Mata. Penerbit: Andi. Yogyakarta. 
Maharani, M.A., 2018. Analisa dan Perancangan Sistem Informasi dengan Codeigniter dan Laravel. Penerbit: Lokomedia. Yogyakarta.

Munawar. 2018. Analisis Perancangan Sistem Berorientasi Objek Dengan UML (Unified Modeling Language). Penerbit: Informatika Bandung. Bandung.

Nugroho, Bunafit. 2019. Aplikasi Pemrograman Web Dinamis Dengan PHP dan MYSQL. Penerbit: Gava Media. Yogyakarta.

Putri, Resthie Rachmanta. 2019. 12 Jenis Diabetes Melitus yang Mungkin Mengintai Anda. https://www.klikdokter.com/infosehat/read/3629207/12-jenis-diabetes-melitus-yangmungkin-mengintai-anda. 24 Juni 2019 (12:30 WIB).

Ramadhan, P. S., dan Pane, U.F.S., 2018. Mengenal Metode Sistem Pakar. Cetakan Pertama. Penerbit: Uais Inspirasi Indonesia. Ponorogo.

S, Rosa A., dan Shalahuddin, M. 2018. Rekayasa Perangkat Lunak. Penerbit: Informatika Bandung. Bandung.

Sa'ad, M. Ibnu. 2020. Otodidak Web Programming: Membuat Website Edutainment. Penerbit: PT Elex Media Komputindo. Jakarta.

Sadewa, I. and Siahaan, K., 2016. Analisis dan Perancangan Sistem Informasi Unit Kegiatan Mahasiswa (UKM) Berbasis Web pada Universitas Batanghari. Jurnal Manajemen Sistem Informasi, 1(2): 135-146.

Saleh, A., 2016. Implementasi Metode Klasifikasi Naive Bayes Dalam Memprediksi Besarnya Penggunaan Listrik Rumah Tangga. Creative Information Technology Journal, 2(3): 207-217.

Saputra, Agus. 2018. Panduan Praktis Dan Jitu Menguasai Framework CodeIgniter 3. Penerbit: CV ASFA Solution. Cirebon.

Tandra, Hans. 2017. Segala Sesuatu Yang Harus Anda Ketahui Tentang Diabetes. Penerbit: Gramedia Pustaka Utama. Jakarta.

Widyorini, E. and Van Tiel, J.M., 2017. Disleksia: Deteksi, Diagnosis, Penanganan di Sekolah dan di Rumah. Edisi Pertama. Cetakan Pertama. Penerbit: Prenada. Jakarta. 